\title{
Analisis Faktor-Faktor yang Mempengaruhi Alokasi Infak Rumah Tangga: Studi Kasus di Desa Pasir Eurih, Kecamatan Tamansari, Kabupaten Bogor
}

\author{
Analysis of Factors Affecting the Charity Allocation of \\ Household: Case Study in Pasir Eurih Village, Tamansari \\ District, Bogor Regency
}

\author{
Myrella Velika Amanta, Wiwiek Rindayati dan Laily Dwi Arsyianti \\ Departemen Ilmu Ekonomi, Fakultas Ekonomi dan Manajemen, Institut Pertanian Bogor
}

\begin{abstract}
Indonesia is one of countries with the most populous Muslim in the world. Poverty that strikes Muslims is an irony considering Islam is the only divine religion which explicitly requires his people to dispense zakah. Therefore, Zakah, Infaq, and Sadaqah (ZIS) is the potential solution to eradicate poverty in Indonesia. Infaq can be an alternative solution to alleviate poverty through income equalization. This study analyses factors that affect the household's charity allocation using Ordinary Least Square (OLS) method and behavior of charity allocations on household using descriptive analysis. Result shows that altruism, income and formal education affect household's charity allocation. These three factors positively influence the amount of household's charity. On the other hand, behavior on charity allocation shows a good respond even though it is not yet a priority.
\end{abstract}

Keywords: Infaq, Poverty, Ordinary Least Square (OLS), Households

\begin{abstract}
Abstrak. Kemiskinan yang melanda umat Islam adalah suatu ironi mengingat agama Islam merupakan satu-satunya agama samawi yang dengan tegas mewajibkan umatnya untuk mengeluarkan zakat. Zakat Infak Sedekah (ZIS) di Indonesia memiliki potensi yang besar mengingat bahwa mayoritas penduduk indonesia adalah muslim. Infak dapat dijadikan alternatif yang tepat sebagai sarana untuk memeratakan pendapatan sehingga dapat mengentaskan kemiskinan. Penelitian ini menganalisis faktor-faktor yang mempengaruhi alokasi infak rumah tangga dengan menggunakan metode Ordinary Least Square (OLS) serta perilaku pengalokasian infak pada rumah tangga dengan menggunakan analisis deskriptif. Hasil analisis menunjukkan faktor-faktor yang mempengaruhi alokasi infak rumah tangga adalah kepekaan sosial (altruisme), pendapatan serta lamanya mendapatkan pendidikan formal. Ketiga faktor tersebut memiliki pengaruh positif terhadap besarnya alokasi infak rumah tangga. Sedangkan untuk perilaku pengalokasian infak pada rumah tangga dapat disimpulkan sudah cukup baik walaupun infak belum menjadi prioritas yang utama.
\end{abstract}

Kata kunci: Infak, Kemiskinan, Ordinary Least Square (OLS), Rumah Tangga 


\section{PENDAHULUAN}

Indonesia masih sangat lekat dengan kemiskinan padahal Indonesia memiliki lahan yang sangat luas dengan berbagai potensi sumber daya alam yang melimpah dan tersusun rapih atas ribuan pulau. Namun jumlah penduduk miskin (penduduk dengan pengeluaran per kapita per bulan di bawah garis kemiskinan) mengalami peningkatan dalam kurung waktu satu tahun yaitu pada tahun 2013 meskipun pada tahun sebelumnya jumlah penduduk miskin telah berkurang, seperti data pada Tabel 1 di bawah ini :

Tabel 1 Data Jumlah Penduduk Miskin di Indonesia Tahun 2007-2013

\begin{tabular}{ccc}
\hline Periode & $\begin{array}{c}\text { Jumlah penduduk miskin } \\
\text { (ratus jiwa) }\end{array}$ & $\begin{array}{c}\text { Persentase penduduk } \\
\text { miskin (\%) }\end{array}$ \\
\hline Maret 2007 & 371,683 & 16.58 \\
Maret 2008 & 349,633 & 15.42 \\
Maret 2009 & 325,300 & 14.15 \\
2010 & 310,234 & 13.33 \\
2011 & $300,189.3$ & 12.49 \\
Maret 2012 & 291,324 & 11.96 \\
September 2012 & 285,946 & 11.66 \\
Maret 2013 & $280,665.5$ & 11.37 \\
September 2013 & $285,539.3$ & 11.47 \\
\hline
\end{tabular}

Sumber : Badan Pusat Statistik (BPS) 2013

Secara umum angka kemiskinan di Indonesia dalam kurung waktu antara tahun 2007 hingga 2012 hanya turun sekitar 5\%. Namun pada tahun 2013 jumlah penduduk miskin justru meningkat. Menurut Bappenas (2012), target tingkat kemiskinan di Indonesia pada tahun 2014 sebesar 8-10\%. Namun apabila dilihat data yang tersedia saat ini, target tersebut sulit untuk dicapai. Berdasarkan data Badan Pusat Statistik, Provinsi Jawa Barat menduduki peringkat ketiga dengan jumlah penduduk miskin terbanyak di Indonesia. Data jumlah penduduk miskin di Jawa Barat dapat dilihat pada tabel di bawah ini :

Tabel 2 Data Jumlah Penduduk Miskin di Provinsi Jawa Barat Tahun 2007-2013

\begin{tabular}{ccc}
\hline Periode & $\begin{array}{c}\text { Jumlah Penduduk Miskin } \\
\text { (Ratus Jiwa) }\end{array}$ & $\begin{array}{c}\text { Persentase } \\
\text { Penduduk Miskin (\%) }\end{array}$ \\
\hline Maret 2007 & 54579 & 13.55 \\
Maret 2008 & 53224 & 13.01 \\
Maret 2009 & 49836 & 11.96 \\
2010 & 47737 & 11.27 \\
2011 & 46486.3 & 10.65 \\
Maret 2012 & 44775 & 10.09 \\
September 2012 & 44215 & 9.89 \\
Maret 2013 & 42970.4 & 9.52 \\
Septmber 2013 & 43826.5 & 9.61 \\
\hline
\end{tabular}

Sumber : Badan Pusat Statistik (BPS) 2013

Berdasarkan data di atas dapat diketahui bahwa jumlah penduduk miskin di Jawa Barat meningkat 85.61 ribu jiwa dalam kurung waktu 6 bulan terakhir yaitu pada bulan Maret sampai September 2013. Selain kemiskinan, gini ratio (rasio dari suatu kemerataan untuk mengukur ketimpangan pendapatan rakyat suatu negara atau daerah) di Provinsi Jawa Barat juga meningkat seperti Gambar 1 di bawah ini: 


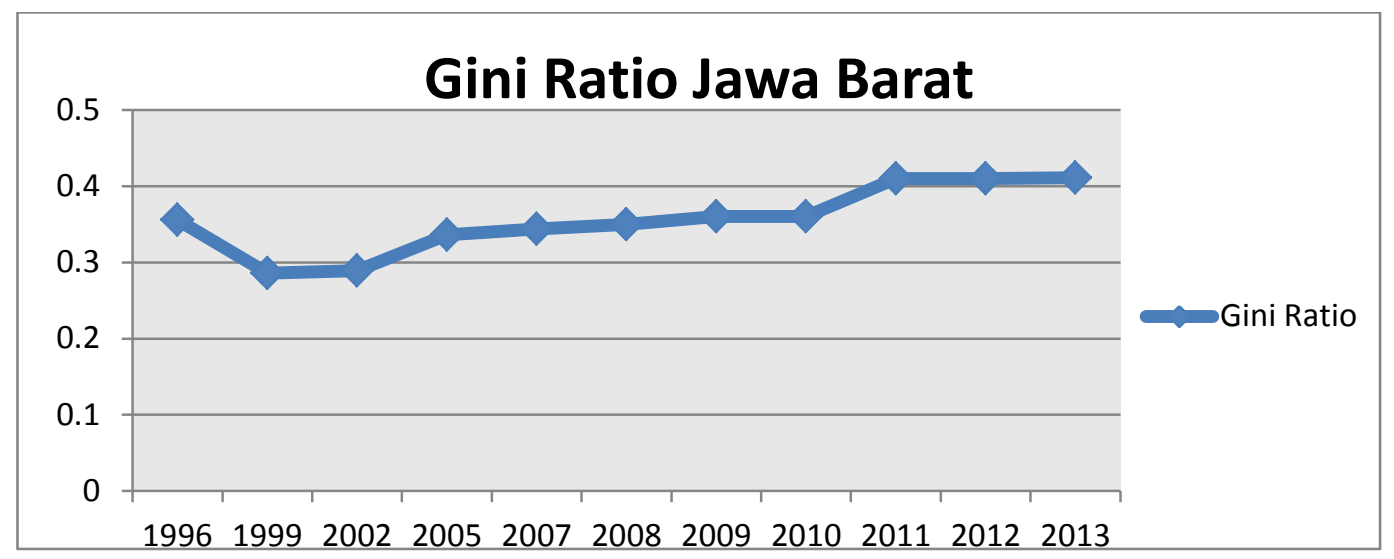

Sumber : Badan Pusat Statistik (2013)

\section{Gambar 1 Gini Ratio Provinsi Jawa Barat Periode 1996-2013}

Berdasarkan sensus Badan Pusat Statistik (BPS) tahun 2010, penduduk Indonesia yang memeluk agama Islam sebanyak 87,20 \% dari total populasi sebesar 208 juta jiwa atau bertambah sekitar 36 juta jiwa dalam kurun waktu 10 tahun. Menurut Mas'udi, et al. (2004) kemiskinan yang melanda umat Islam adalah suatu ironi mengingat agama Islam merupakan satu-satunya agama samawi yang dengan tegas mewajibkan umatnya untuk mengeluarkan zakat. Di antara ajaran agama Islam yang dapat mengatasi problema sosial dalam masyarakat adalah zakat dan infak. Menurut Beik (2010) dalam Beik, et al. (2011) zakat merupakan ibadah yang memiliki tiga dimensi pokok, yaitu dimensi spiritual personal, dimensi sosial dan dimensi ekonomi. Berdasarkan QS. Al-Baqarah ayat 275281, ada tiga sektor penting dalam perekonomian menurut Al-Quran, yang pertama adalah sektor riil yaitu bisnis dan perdagangan, yang kedua adalah sektor keuangan atau moneter (diindikasikan oleh larangan riba), dan yang ketiga adalah zakat infak dan sedekah (ZIS). ZIS di Indonesia memiliki potensi yang besar mengingat kembali bahwa mayoritas penduduk indonesia adalah muslim (meskipun instrumen tersebut, terutama infak dan sedekah, tidak hanya secara spesifik dikhususkan pada umat Islam). Oleh karena itu Zakat, Infak dan Sedekah (ZIS) dapat dijadikan alternatif sebagai sarana untuk memeratakan pendapatan sehingga dapat mengentaskan kemiskinan. Potensi zakat rumah tangga nasional (dengan nisab beras) wilayah Jawa Barat memiliki potensi zakat terbesar yaitu sekitar 17.668 Milyar. Dalam hal ini, dapat disimpulkan bahwa jumlah penduduk muslim pada suatu daerah ikut mempengaruhi tingkat potensi zakat di daerah tersebut (Mukhlis dan Beik, 2013).

Zakat merupakan salah satu bentuk berinfak. Namun zakat memiliki sifat-sifat khusus. Sedangkan infak memiliki arti mengeluarkan sesuatu (harta) untuk kepentingan sesuatu. Termasuk ke dalam pengertian ini, infak yang dikeluarkan orang kafir untuk kepentingan agamanya seperti pada QS. Al-Anfal ayat 36. Menurut terminologi syariah infak berarti mengeluarkan sebagian dari harta atau pendapatan (penghasilan) untuk suatu kepentingan yang diperintahkan ajaran Islam. Jika zakat memiliki nisab, infak tidak memiliki nisab. Infak dikeluarkan oleh setiap orang yang beriman, baik yang memiliki penghasilan tinggi maupun rendah, apakah saat ia lapang maupun sempit seperti pada QS. Ali Imran ayat 134. Infak dapat diberikan kepada siapa pun misalnya untuk kedua orang tua, kaum kerabat, anak-anak yatim, orang-orang miskin atau sebagainya sesuai dengan QS. AlBaqarah ayat 215. Berinfak adalah ciri mukmin yang memiliki iman dengan sungguhsungguh seperti pada QS. Al-Anfal ayat 3-4. Zakat memiliki aturan-aturan atau batasanbatasan yang ketat dan wajib dikeluarkan untuk membersikan harta, sedangkan infak dapat dikeluarkan oleh siapa pun, untuk siapa pun, kapan pun dan berapa pun. Infak memiliki lingkup yang lebih luas apabila dibandingkan dengan zakat, buktinya jika 
seseorang telah berzakat tetapi masih memiliki kelebihan harta sangat dianjurkan untuk berinfak. Indonesia memiliki potensi infak yang sangat besar. Jika dihitung, potensi infak yang akan dikumpulkan dari GINA (Gerakan Infak nasional, yaitu infak kolektif yang dipotong dari gaji pegawai pemerintah seluruh Indonesia) adalah sebesar Rp 178.9 miliar pertahun. Dengan asumsi jumlah PNS, TNI/ABRI dan karyawan BUMN seluruh Indonesia sebanyak 9350455 orang, yang apabila berinfak antara 1.000 s.d 10.000 per bulan akan terkumpul hampir 15 juta rupiah.

Berdasarkan uraian latar belakang di atas, maka perumusan masalah yang akan diteliti adalah sebagai berikut :

1. Bagaimana karakteristik sosial demografi ekonomi (besar keluarga, usia, tingkat pendidikan dan pendapatan) di desa Pasir Eurih, Kecamatan Tamansari, Kabupaten Bogor?

2. Bagaimana pengaruh faktor pekerjaan, pendidikan, pendapatan, besar keluarga, keimanan, penghargaan, altruisme (kepekaan sosial) dan kepuasan diri terhadap alokasi infak pada rumah tangga di desa Pasir Eurih, Kecamatan Tamansari, Kabupaten Bogor?

3. Bagaimana perilaku pengalokasian infak pada rumah tangga di desa Pasir Eurih, Kecamatan Tamansari, Kabupaten Bogor?

Berdasarkan rumusan masalah yang telah diuraikan sebelumnya, maka tujuan dilakukannya penelitian ini antara lain :

1. Mempelajari karakteristik sosial demografi ekonomi (besar keluarga, usia, tingkat pendidikan dan pendapatan) di desa Pasir Eurih, Kecamatan Tamansari, Kabupaten Bogor.

2. Menganalisis pengaruh faktor pekerjaan, pendidikan, pendapatan, besar keluarga, keimanan, penghargaan, altruisme (kepekaan sosial) dan kepuasan diri terhadap alokasi infak pada rumah tangga di desa Pasir Eurih, Kecamatan Tamansari, Kabupaten Bogor.

3. Mempelajari perilaku pengalokasian infak pada rumah tangga di desa Pasir Eurih, Kecamatan Tamansari, Kabupaten Bogor.

\section{TINJAUAN PUSTAKA}

Mas'udi (2004) menyatakan Al-Quran sudah sejak awal menawarkan solusi untuk mengatasi masalah kemiskinan dan ketimpangan pembagian pendapatan dengan cara memasukkan kegiataan zakat sebagai salah satu rukun Islam. Hal ini menunjukkan betapa pentingnya peran zakat dalam kehidupan seorang Muslim. Ditinjau dari sudut syariah Islam, maka tujuan berzakat adalah untuk membersihkan harta dan jiwa. Pengeluaran zakat harta untuk membersihkan harta kita, karena dalam harta tersebut sebagian merupakan hak orang miskin. Dengan demikian, untuk mengatasi kemiskinan, Islam dengan tegas mewajibkan untuk berpartisipasi langsung dalam kegiatan tersebut. Ditinjau dari sudut ekonomi, zakat merupakan salah satu variabel inti di dalam sistem ekonomi Islam di samping penghapusan kegiatan ribawi.

Pusat Pengkajian dan Pengembangan Ekonomi Islam (2008) menyatakan kebahagiaan merupakan tujuan utama kehidupan manusia. Manusia akan memperoleh kebahagiaan ketika seluruh kebutuhan dan keinginannya terpenuhi, baik dalam aspek material maupun 
spiritual, dalam jangka pendek maupun jangka panjang. Terpenuhinya kebutuhan yang bersifat material, seperti sandang, rumah, dan kekayaan lainnya, dewasa ini lebih banyak mendapatkan perhatian dalam ilmu ekonomi. Namun falah yang memiliki arti kemuliaan dan kemenangan dalam hidup harus dapat menjadi tujuan hidup setiap umat muslim. Istilah falah menurut Islam diambil dari kata dalam Al-Quran, yang sering dimaknai sebagai keberuntungan jangka panjang, dunia dan akhirat, sehingga tidak hanya memandang aspek material namun justru lebih ditekankan pada aspek spiritual. Karena itulah kehidupan dunia merupakan ladang bagi pencapaian tujuan akhirat. Meskipun demikian, falah mengandung makna kondisi maksimum dalam kebahagiaan di dunia dan di akhirat. Ibadah merupakan alat atau jalan yang digunakan untuk mencapai falah.

Arsyanti (2013) menyatakan sumberdaya keuangan yang diperoleh sebaiknya dialokasikan untuk empat komponen utama dengan prioritas sebagai berikut Charity (donasi), Debt (utang dan tagihan), Investment (investasi), dan Consumption (konsumsi) yang disingkat dengan CDIC. Harta yang diperoleh sebaiknya dialokasikan pertama kali untuk donasi. Donasi terdiri dari dua, yaitu wajib dan sukarela. Prioritas kedua adalah utang, utang termasuk tagihan-tagihan bulanan. Utang yang dimaksud adalah segala sesuatu yang harus atau menjadi kewajiban yang dibayarkan dan sudah jatuh tempo. Utang menjadi komponen prioritas karena termasuk ke dalam kategori krusial, bahkan seorang syahid akan terhalang langkahnya memasuki surga jika utangnya belum dilunasi. Prioritas selanjutnya adalah investasi, investasi yang abadi atau tujuan investasi dalam Islam sebenarnya ada tiga, yaitu investasi jariyah, investasi ilmu yang bermanfaat, dan investasi anak shaleh yang mendoakan. Komsumsi merupakan komponen prioritas yang terakhir, karena konsumsi dapat menjadi godaan atau ujian. Konsumsi hendaknya ditujukan untuk memenuhi kebutuhan.

\section{METODE PENELITIAN}

\section{Jenis dan Sumber Data}

Data yang digunakan dalam penelitian ini adalah data primer dan sekunder. Data primer adalah data utama yang dipakai dalam penelitian ini, diambil dengan menggunakan metode wawancara dengan kuesioner. Data sekunder didapat dari pusat pemerintahan desa, literatur atau dokumen-dokumen baik yang dipublikasikan maupun tidak dipublikasikan terkait tema penelitian.

\section{Lokasi dan Waktu Penelitian}

Penelitian ini dilaksanakan di Desa Pasir Eurih, Kecamatan Tamansari, Kabupaten Bogor. Penentuan lokasi ini dilakukan secara purposive (sengaja) dengan mempertimbangkan desa ini memiliki potensi infak yang besar. Penelitian dilakukan pada bulan Maret hingga pertengahan April 2014.

\section{Metode Pengumpulan Data}

Data yang dikumpulkan dalam peneltian ini diambil dengan menggunakan metode studi kasus (case study) melalui wawancara kepada warga Desa Pasir Eurih, Kecamatan Tamansari, Kabupaten Bogor yang menjadi responden dengan menggunakan kuesioner. Jumlah sample yang diambil dalam penelitian ini berjumlah 60 orang. Dalam hal ini, masyarakat yang menjadi responden adalah penduduk muslim yang pernah mengalokasikan pendapatannya untuk diinfakkan. 


\section{Metode Pengolahan dan Analisis Data}

Penelitian ini menggunakan dua alat analisis data, yaitu analisis deskriptif dan regresi linier berganda dengan menggunakan software SPSS 16. Pengolahan data menggunakan Microsoft Excel 2010 untuk tabulasi data.

\section{Analisis Deskriptif}

Analisis deskriptif dalam penelitian ini digunakan untuk menjelaskan karakteristik sosial demografi ekonomi serta perilaku berinfak pada rumah tangga responden. Selain itu analisis deskriptif juga digunakan untuk menjelaskan hasil kuesioner.

\section{Analisis Regresi Linier Berganda}

Analisis regresi linier berganda dalam penelitian ini digunakan untuk mencari faktorfaktor apa saja yang berpengaruh terhadap alokasi infak rumah tangga. Metode kuadrat terkecil biasa (method of Ordinary Least Square, OLS) dapat dijelaskan melalui pendekatan (Gujarati \& Zain, 1999). Berikut model regresi linier berganda dalam penelitian ini :

$$
\mathrm{Y}=\beta_{\mathrm{o}}+\beta_{1} \mathrm{X}_{1}+\beta_{2} \mathrm{X}_{2+} \beta_{3} \mathrm{X}_{3+\cdots \cdots} \ldots+\beta_{\mathrm{n}} \mathrm{Xn}+\mu_{\mathrm{i}}
$$

Keterangan :

$\mathrm{Y}=$ Alokasi infak rumah tangga (dalam nominal rupiah)

$\beta o=$ Intersept

$\beta_{\mathrm{j}}=$ Parameter regresi peubah bebas ke-j

$\mathrm{X}_{1}=$ Keimanan

$\mathrm{X}_{2}=$ Penghargaan

$\mathrm{X}_{3}=$ Altruisme

$\mathrm{X}_{4}=$ Kepuasaan diri

$\mathrm{X}_{5}=$ Lama mendapatkan pendidikan (dalam tahun)

$\mathrm{X}_{6}=$ Total pendapatan rumah tangga (dalam nominal rupiah)

$\mathrm{X}_{7}=$ Jumlah tanggungan (orang)

$\mathrm{X}_{8}=$ Dummy jenis pekerjaan utama

$\mathrm{D}_{1}=$ petani

$\mathrm{D}_{2}=$ Pedagang

$\mathrm{D}_{3}=$ Buruh

$\mathrm{D}_{4}=$ Perangkat desa (pemerintahan)

$\mathrm{D}_{5}=$ Pengrajin sepatu/sandal 


\section{HASIL DAN PEMBAHASAN}

\section{Karakteristik Responden dan Kepala Keluarga}

Hasil karakteristik responden dan kepala keluarga ini menggunakan metode wawancara terhadap 60 responden di Desa Pasir Eurih, Kecamatan Tamansari, Kabupaten Bogor. Karakteristik responden dilihat dari kondisi demografi yakni jenis kelamin. Mayoritas responden yang ditemui adalah perempuan sekitar 58\% atau 35 jiwa, sedangkan sisanya $42 \%$ atau 25 jiwa adalah laki-laki. Karakteristik kepala keluarga juga dilihat dari kondisi demografi yakni usia, pendidikan, pekerjaan utama, jumlah tanggungan, serta pendapatan per bulan sebagaimana ditunjukkan dalam Tabel 3 berikut :

Tabel 3 Demografi kepala keluarga

\begin{tabular}{|c|c|c|c|}
\hline & Variabel & $\begin{array}{c}\text { Jumlah } \\
\text { (jiwa) }\end{array}$ & $\begin{array}{c}\text { Persentase } \\
(\%)\end{array}$ \\
\hline \multirow[t]{4}{*}{ Usia } & Dibawah 30 tahun & 4 & 7 \\
\hline & $30-39$ & 28 & 46 \\
\hline & $40-49$ & 15 & 25 \\
\hline & 50 atau lebih & 13 & 22 \\
\hline \multirow[t]{4}{*}{ Lama pendidikan } & Lulus SD atau dibawahnya & 42 & 70 \\
\hline & Pernah merasakan SMP & 7 & 12 \\
\hline & Pernah merasakan SMA & 9 & 15 \\
\hline & Pernah merasakan kuliah & 2 & 3 \\
\hline \multirow[t]{6}{*}{ Pekerjaan } & Petani & 1 & 2 \\
\hline & Pedagang & 3 & 5 \\
\hline & Buruh & 20 & 33 \\
\hline & Perangkat desa & 2 & 3 \\
\hline & Pengrajin sepatu/sendal & 24 & 40 \\
\hline & Lainnya & 10 & 17 \\
\hline \multirow[t]{6}{*}{ Jumlah tanggungan } & 2 & 5 & 8 \\
\hline & 3 & 19 & 32 \\
\hline & 4 & 20 & 33 \\
\hline & 5 & 10 & 17 \\
\hline & 6 & 4 & 7 \\
\hline & 7 & 2 & 3 \\
\hline \multirow[t]{5}{*}{ Pendapatan } & $<\mathrm{Rp} 500.000$ & 5 & 8 \\
\hline & Rp 500 ribu $-<\operatorname{Rp} 1,5$ juta & 20 & 33 \\
\hline & Rp 1,5 juta $-<\operatorname{Rp} 2,5$ juta & 18 & 30 \\
\hline & $\operatorname{Rp} 2,5$ juta $-<\operatorname{Rp} 5$ juta & 11 & 19 \\
\hline & $>$ Rp 5 juta & 6 & 10 \\
\hline
\end{tabular}

Sumber : Data Primer 2014 (diolah)

Mayoritas kepala keluarga di Desa Pasir Eurih berusia 30-39 tahun sebanyak 28 jiwa atau 46\% namun didominasi oleh usia 32 tahun. Untuk tingkat pendidikan dapat dilihat bahwa tingkat pendidikan masyarakat Desa Pasir Eurih masih sangat rendah, karena 70\% kepala keluarga hanya lulusan SD atau bahkan dibawahnya. Ini dapat disebabkan karena mayoritas pekerjaan di Desa Pasir Eurih adalah pengrajin sepatu sehingga masyarakat desa ini menganggap tidak memerlukan pendidikan yang tinggi. Besar keluarga di Desa Pasir Eurih didominasi oleh besar keluarga 4 dan 3 anggota, masing-masing sebesar 20 jiwa dan 19 jiwa. Untuk penghasilan didominasi oleh penghasilan 500 ribu rupiah sampai 1.5 juta rupiah sebanyak 20 responden atau $33 \%$. 
Karakteristik keluarga selanjutnya dapat dilihat dari kepemilikan aset keluarga di Desa Pasir Eurih. Kepemilikan aset di Desa Pasir Eurih sudah cukup baik seperti dapat dilihat pada tabel 4 di bawah ini :

Tabel 4 Kepemilikan Aset Responden Penelitian di Desa Pasir Eurih, Kecamatan Tamansari, Kabupaten Bogor, Jawa Barat

\begin{tabular}{lcc}
\hline \multicolumn{1}{c}{ Aset } & $\begin{array}{c}\text { Jumlah Pemilik } \\
\text { (jiwa) }\end{array}$ & Persentase (\%) \\
\hline Rumah & 54 & 90 \\
Tanah/Sawah & 16 & 27 \\
Motor & 35 & 58 \\
Emas & 17 & 28 \\
Tidak Memilik Aset Apapun & 3 & 5 \\
\hline
\end{tabular}

Sumber : Data Primer 2014 (diolah)

Berdasarkan Tabel 4 di atas dapat dilihat bahwa 90\% atau 54 responden sudah memiliki aset berupa rumah bahkan $58 \%$ sudah memiliki kendaraan bermotor roda dua namun di desa ini masih terdapat 5\% atau sebanyak 3 kepala keluarga tidak memiliki aset apapun. Selain itu dapat dilihat juga bahwa tidak ada satu pun warga Desa Pasir Eurih yang memiliki kendaraan bermotor roda empat. Namun ternyata kebiasaan warga dalam menabung atau menyisihkan sebagian pendapatannya untuk disimpan sudah sangat baik. Berdasarkan hasil lapang, $80 \%$ atau 48 responden rutin menyisihkan pendapatan setiap minggu. Mayoritas masyarakat di desa ini menyisihan pendapatan untuk ditabung dengan cara mengikuti arisan, dapat dilihat seperti gambar 2 di bawah ini :

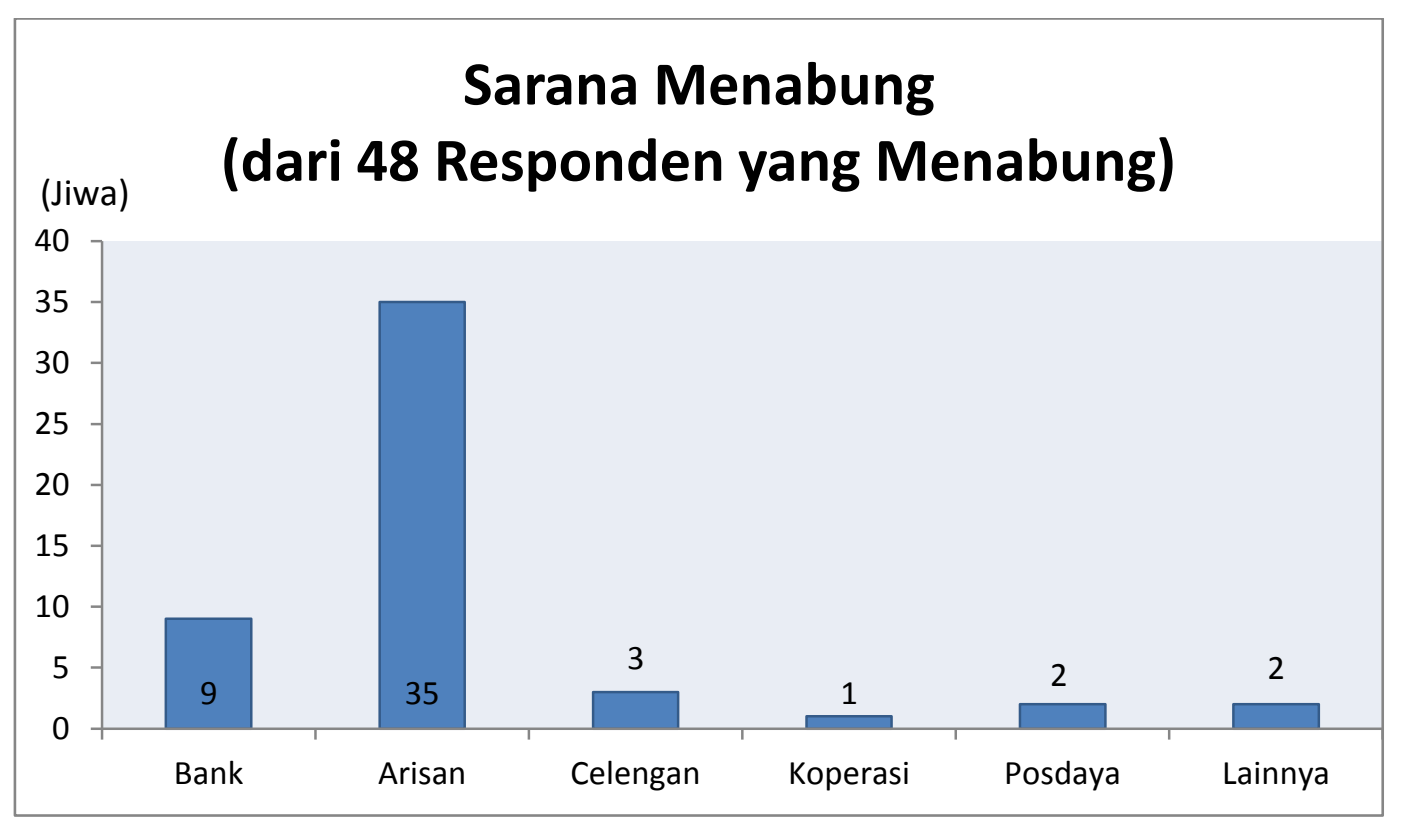

Sumber : Data Primer 2014 (diolah)

Gambar 2 Sarana Menabung Responden Penelitian di Desa Pasir Eurih, Kecamatam Tamansari, Kabupaten Bogor, Jawa Barat 
Berdasarkan gambar 2 di atas dapat dilihat bahwa dari 48 responden yang rutin menyisihkan pendapatan sebanyak 35 responden atau sekitar $73 \%$ menyisihkan pendapatan melalui sistem/metode arisan. Sistem arisan memang populer di desa ini. Warga yang mengikuti sistem ini, dengan sukarela mengalokasikan pendapatannya untuk kegiatan ini bahkan dana yang dialokasikan untuk mengikuti arisan dapat dikatakan tinggi. Nominal uang paling tinggi yang disisihkan dengan menggunakan sistem arisan adalah 2 juta rupiah per bulannya, padahal pendapatan per bulannya hanya 5 juta rupiah. Sistem arisan di desa ini biasanya menggunakan periode per minggu.

\section{Faktor-Faktor yang Mempengaruhi Alokasi Infak Rumah Tangga}

Untuk mengentas kemiskinan di Indonesia khususnya di daerah Bogor dapat dilakukan dengan pemerataan pendapatan sehingga tidak terjadi ketimpangan ekonomi. Infak dapat menjadi alternatif yang tepat mengingat mayoritas penduduk Indonesia memeluk agama Islam. Analisis faktor-faktor yang mempengaruhi alokasi infak rumah tangga dilakukan dengan metode Ordinary Least Square (OLS).

Hasil dari metode OLS menunjukkan nilai $R$-square sebesar 46.80 yang artinya $46.80 \%$ keragamaan alokasi infak dapat dijelaskan oleh masing-masing variabel penjelas dalam model, sedangkan sisanya dapat dijelaskan oleh variabel-variabel lain yang tidak dimasukkan ke dalam model. Hasil olahan data dengan model OLS pada penelitian ini tidak terdapat pelanggaran apapun, yang dimaksud dengan pelanggaran yaitu pelanggaran normalitas, heteroskedastisitas, autokorelasi maupun multikolinearitas. Hal ini dibuktikan oleh nilai probabilitas (uji Kolmogorov-Smirnov), nilai probabilitas (uji Glejser), nilai Runs Test serta nilai VIF (Varian Inflated Factor). Dari hasil regresi pada penelitian ini, dengan taraf nyata $10 \%$, ada tiga variabel yang berbeda nyata yaitu altruisme (kepekaan sosial), pendapatan dan pendidikan. Namun pada taraf nyata 5\% hanya ada dua variabel yang berbeda nyata, yaitu variabel altruisme serta pendapatan seperti dapat dilihat pada tabel 5 di bawah ini :

Tabel 5 Faktor-Faktor yang Mempengaruhi Alokasi Infak Rumah Tangga

\begin{tabular}{lcc}
\hline \multirow{2}{*}{ Variabel } & \multicolumn{2}{c}{ Model OLS } \\
\cline { 2 - 3 } Konstanta & Parameter & P-value \\
Keimanan & 5.022 & 0.007 \\
Penghargaan & -0.026 & 0.574 \\
Altruisme & 0.273 & 0.176 \\
Kepuasaan diri & 0.211 & $0.045^{* *}$ \\
D1 & 0.083 & 0.526 \\
D2 & -1.225 & 0.272 \\
D3 & 0.759 & 0.257 \\
D4 & 0.205 & 0.617 \\
D5 & -0.267 & 0.738 \\
Pendidikan & 0.500 & 0.206 \\
Pendapatan & 0.088 & $0.077^{*}$ \\
Jumlah tanggungan & $2.014 \times 10^{-7}$ & $0.035^{* *}$ \\
\hline
\end{tabular}

Keterangan : *signifikan pada taraf nyata $10 \%$

**signifikan pada taraf nyata $5 \%$

Altruisme (kepekaan sosial) memiliki pengaruh positif terhadap besarnya alokasi infak rumah tangga yang berarti semakin tinggi kepekaan sosial responden maka akan semakin tinggi pula alokasi infak rumah tangga responden. Nilai koefisien parameter altruisme sebesar 0.211 dan signifikan pada taraf nyata 5\%. Hal ini dapat diartikan bahwa 
peningkatan altruisme sebesar satu satuan akan meningkatkan nilai $\ln (\mathrm{Y})$ atau nilai $\ln$ dari alokasi infak rumah tangga sebesar 0.211. Apabila dilakukan transformasi balik dan jika dimisalkan kepekaan sosial meningkat satu satuan dan lainnya dianggap nol, maka nilai perubahan alokasi infak adalah sebesar 44.0117 rupiah.

Variabel pendidikan memiliki pengaruh positif terhadap besarnya alokasi infak rumah tangga yang berarti semakin tinggi pendidikan kepala rumah tangga responden maka akan semakin tinggi pula alokasi infak rumah tangga responden. Nilai koefisien parameter pendidikan sebesar 0.088 dan signifikan pada taraf nyata $10 \%$. Hal ini dapat diartikan bahwa peningkatan pendidikan sebanyak satu tahun akan meningkatkan nilai $\ln (\mathrm{Y})$ atau nilai ln dari alokasi infak rumah tangga sebesar 0.088. Apabila dilakukan transformasi balik dan jika dimisalkan pendidikan meningkat satu tahun dan lainnya dianggap nol, maka nilai perubahan alokasi infak adalah sebesar 15.2397 rupiah. Hal ini sesuai dengan penelitian Alhasanah (2011) yang menyatakan bahwa responden dengan pendidikan akhir lebih tinggi, persentase membayar infak secara rutin lebih besar.

Variabel pendapatan memiliki pengaruh positif terhadap besarnya alokasi infak rumah tangga yang berarti semakin tinggi total pendapatan rumah tangga maka akan semakin tinggi pula alokasi infak rumah tangga tersebut. Nilai koefisien parameter pendapatan sebesar 2.014x10-7 dan siginifikan pada taraf nyata 5\%. Hal ini dapat diartikan bahwa peningkatan pendapatan sebesar satu rupiah akan meningkatkan nilai ln (Y) atau nilai $\ln$ dari alokasi infak rumah tangga sebesar 2.014x10-7 atau dengan kata lain dapat dikatakan bahwa peningkatan pendapatan sebesar satu juta rupiah akan meningkatkan nilai $\ln (\mathrm{Y})$ sebesar 0.2014. Apabila dilakukan transformasi balik dan jika dimisalkan pendapatan meningkat satu juta rupiah dan lainnya dianggap nol, maka nilai perubahan alokasi infak adalah sebesar 41.4019 rupiah. Hal ini sesuai dengan penelitian Hughes dan Luksetich dalam Burhan, et al., yang menyatakan bahwa pendapatan permanen keluarga memiliki efek yang positif kuat dan signifikan secara statistik terhadap total amal sedekah keluarga.

Variabel yang dianggap sangat memengaruhi perilaku seseorang dalam mengeluarkan zakat, infak, maupun sedekah (ZIS) yaitu karena faktor keimanan. Seperti halnya dalam penelitian Sariningrum (2011) yang menyatakan bahwa keimanan merupakan faktor utama yang menjadi alasan seseorang untuk berzakat. Namun dalam penelitian ini, keimanan tidak berpengaruh nyata terhadap alokasi infak rumah tangga. Berdasarkan hasil lapang, warga Desa Pasir Eurih memang mengeluarkan infak bukan karena mereka memiliki tingkat kereligiusan yang baik. Melainkan karena nilai gotong royong yang lebih dominan dalam sikap masyarakat, sehingga infak yang mereka keluarkan bukan semata-mata karena ingin mendapatkan pahala atau karena nilai agama yang sudah tertanam secara baik dalam diri warga, melainkan karena sikap ingin membantu orang lain serta kepekaan sosial yang tinggi.

Variabel-variabel yang lain yang tidak berpengaruh nyata pada penelitian ini yaitu seperti penghargaan, kepuasan diri, dummy pekerjaan dan jumlah tanggungan. Sehingga dapat disimpulkan bahwa rumah tangga di Desa Pasir Eurih dalam mengalokasikan infak tidak dipengaruhi oleh variabel-variabel tersebut. Misalnya penghargaan, masyarakat di wilayah tersebut menginfakkan pendapatannya bukan untuk dilihat atau dihargai oleh orang lain. Selain itu alasan utamanya juga bukan hanya untuk merasakan kepuasaan tersendiri apabila telah mengeluarkan infak, sehingga dapat dilihat bahwa variabel kepuasaan diri tidak berpengaruh secara nyata. Tidak signifikannya dummy pekerjaan memiliki arti bahwa apapun pekerjaan masyarakat di desa ini, ternyata tidak memengaruhi alokasi infak rumah tangga tersebut. Selanjutnya tidak signifikannya jumlah tanggungan dalam penelitian ini, dapat disebabkan karena terlalu homogennya 
data jumlah tanggungan di desa ini, karena mayoritas jumlah tanggungan per kepala keluarga di desa ini adalah 3 dan 4 jiwa.

\section{Perilaku Pengalokasian Infak di Rumah Tangga}

Infak memiliki ruang lingkup yang lebih luas apabila dibandingkan dengan zakat. Maka infak dapat diberikan kepada siapa pun namun harus dalam bentuk materi. Di bawah ini terdapat data responden yang merasa sering memberikan infak kepada kategori-kategori penerima infak :

Tabel 6 Sasaran Infak

\begin{tabular}{ccc}
\hline Penerima infak & Jumlah responden (jiwa) & $\begin{array}{c}\text { Persentase responden } \\
(\boldsymbol{\%})\end{array}$ \\
\hline Pengemis/Pengamen & 19 & 18 \\
Saudara/Keluarga & 12 & 11 \\
Yatim Piatu & 16 & 15 \\
Kotak Infak & 53 & 49 \\
Orang Tua & 6 & 5 \\
Lainnya & 2 & 2 \\
\hline
\end{tabular}

Dapat dilihat bahwa mayoritas responden menyalurkan infak melalui kotak amal. Dari 60 responden yang diwawancarai terdapat 53 jiwa atau $49 \%$ rutin memberikan infak melalui kotak amal. Hal ini sesuai dengan penelitian Alhasanah (2011) yang menyatakan bahwa sebagian besar responden yang rutin berinfak adalah responden yang mengikuti majelis taklim atau kegiatan sosial kemasyarakatan di lingkungannya. Ini karena dalam majelis taklim atau kegiatan sosial tersebut ada infak yang secara rutin dikeluarkan untuk kelancaran kegiatan tersebut. Namun terdapat pula responden yang memberikan langsung kepada pengemis maupun pengamen sebanyak 19 jiwa atau sebesar 18\%. Infak dapat diberikan kepada siapa pun, bahkan menafkahi orang tua pun termasuk dalam prioritas berinfak seperti dijelaskan dalam QS. Al-Baqarah ayat 215 sebagai berikut, bahwa apa saja harta yang kamu nafkahkan hendaklah diberikan kepada ibu-bapak. Berdasarkan hasil data lapang, dari 60 responden terdapat 6 jiwa yang dengan rutin menafkahi orang tuanya setiap bulan. Nominal yang diberikan setiap bulannya berbeda-beda tergantung pendapatan yang diperoleh. Selain 6 responden yang dengan rutin menafkahi orang tua tersebut, terdapat pula responden lain yang akan selalu memberi kepada orang tua apabila mendapatkan pemasukan lebih.

Nominal infak masyarakat Desa Pasir Eurih berdasakan hasil wawancara rata-rata bernilai sekitar 68 ribu rupiah setiap bulannya dengan nominal minimum 4 ribu rupiah per bulan dan nominal maksimum 1 juta rupiah per bulan. Nominal yang paling sering dialokasikannya per rumah tangga adalah 8 ribu rupiah per bulan dengan cara melalui kotak infak, warga biasanya dalam satu minggu mengeluarkan infak sebesar 2 ribu rupiah. Mayoritas masyarakat Desa Pasir Eurih mengeluarkan infak dengan periode per minggu melalui kotak infak setiap solat Jumat maupun saat pengajian atau majelis taklim. Dari 60 responden terdapat 4 responden atau hanya sekitar 7\% yang mengeluarkan infak dengan periode per bulan. Hal ini sesuai dengan pemaparan Alhanasah (2011) yang menyatakan bahwa periode membayar infak yang lebih banyak dipilih oleh responden adalah per minggu baik dilihat dari sisi pendidikan, pekerjaan, dan pendapatan. Periode per minggu dipilih sebagai waktu yang ideal untuk membayar infak karena bisa disalurkan pada saat pelaksanaan solat Jumat dan adanya pemikiran dengan jumlah total 
infak yang sama, terasa lebih ringan dikeluarkan per minggu dibandingan sekaligus pada setiap bulan.

Berdasarkan beberapa data laporan keuangan dana infak di Desa Pasir Eurih dapat disimpulkan bahwa potensi alokasi infak di desa ini sangat baik karena rata-rata penerimaan infak di desa ini per bulannya selalu tinggi. Dana yang digalang melalui swadaya masyarakat juga berjalan dengan baik. Dana swadaya yang dikumpulkan oleh masyarakat digunakan untuk membangun musala atau mesjid serta untuk membantu masyarakat yang sedang mengalami musibah. Namun laporan keuangan yang ada, tidak sistematis dan transparan karena masyarakat tidak pernah mempertanyakan kemana aliran keuangan tersebut. Masyarakat tidak meminta laporan keuangan secara berkala, mereka cukup hanya dengan melihat realisasi dari dana swadaya yang dikumpulkan. Ini mencerminkan bahwa masyarakat di desa ini masih sangat menjunjung tinggi nilai gotong royong dan kepercayaan.

Managemen perencanaan keuangan islami memiliki ciri khas dengan meletakkan charity (zakat, infak, sedekah) sebagai prioritas yang paling utama. Untuk prioritas yang kedua adalah membayar hutang karena hutang adalah kewajiban yang wajib dipenuhi oleh setiap orang yang memilikinya seperti pada hadits berikut : "Orang yang mati syahid diampuni seluruh dosanya, kecuali utang.". Berdasarkan hadis tersebut maka dapat disimpulkan bahwa hutang sangat wajib dipenuhi karena hutang tidak dapat diampuni walaupun yang bersangkutan telah meninggal dunia sekalipun mati syahid. Sedangkan pengeluaran rutin atau konsumsi memiliki prioritas terakhir. Namun ternyata berdasarkan hasil lapang yang didapatkan melalui wawancara kepada 60 responden di Desa Pasir Eurih didapatkan data seperti berikut ini :

Tabel 7 Prioritas Pengeluaran Rumah Tangga

\begin{tabular}{|c|l|c|c|c|c|}
\hline \multirow{2}{*}{ Peringkat } & \multicolumn{1}{|c|}{ Prioritas Dana } & \multicolumn{4}{|c|}{ Pilihan Responden } \\
\cline { 3 - 6 } & & 1 & 2 & 3 & 4 \\
\hline \multirow{2}{*}{1} & Pengeluaran rutin (konsumsi) & 45 & 11 & 3 & 1 \\
\hline 2 & Membayar hutang & 2 & 15 & 18 & 25 \\
\hline 3 & Donasi (Zakat, Infak) & 7 & 29 & 12 & 12 \\
\hline 4 & Investasi & 6 & 5 & 27 & 22 \\
\hline
\end{tabular}

Mayoritas masyarakat masih meletakkan pengeluaran rutin atau konsumsi sebagai prioritas utama, hanya sedikit sekali yang memilih untuk mengeluarkan dahulu kewajiban yang dimilikinya. Manajemen perencanaan keuangan islami meletakkan pengeluaran rutin (konsumsi) pada urutan terakhir karena sesuai dengan QS. Al-Qasas ayat 77.

Ayat tersebut dengan tegas menjelaskan bahwa Allah memerintahkan umat-Nya untuk mencari dahulu kebahagian akhirat namun tanpa melupakan kebahagiaan dunia. Sehingga dapat disimpulkan bahwa kebahagiaan dunia sebenarnya dapat diletakkan sebagai prioritas yang paling akhir. Namun setelah dilakukan scoring ternyata prioritas yang didahulukan oleh masyarakat secara berurutan adalah pengeluaran rutin/konsumsi, donasi (zakat dan infak), investasi baru kemudian diikuti dengan membayar hutang. Hal yang sangat perlu untuk diperhatikan, membayar hutang yang sebenarnya merupakan suatu kewajiban namun pada kenyataan kewajiban ini diletakkan sebagai prioritas terakhir oleh masyarakat. Dapat dilihat dengan pola pengeluaran rumah tangga yang seperti ini, berarti masyarakat masih lebih mendahulukan kepentingan duniawi. Masyarakat Desa Pasir Eurih belum menyadari pentingnya untuk segera melunasi hutang yang dimiliki. Padahal hutang tidak akan hilang begitu saja walapun yang bersangkutan telah meninggal dunia. 
Hutang dapat menghalangi seseorang untuk masuk ke dalam surga. Seperti hadis berikut : "Barangsiapa yang ruhnya terpisah dari jasadnya dan dia terbebas dari tiga hal: [1] sombong, [2] ghulul (khianat), dan [3] hutang, maka dia akan masuk surga."

\section{SIMPULAN DAN SARAN}

\section{Simpulan}

Berdasarkan pemaparan hasil dan pembahasan dalam penelitian ini dapat ditarik beberapa kesimpulan sebagai berikut :

1. Berdasarkan karakteristik sosial demografi ekonomi masyarakat Desa Pasir Eurih, Kecamatan Tamansari, Kabupaten Bogor belum menyadari pentingnya pendidikan sehingga tidak meletakkannya sebagai prioritas yang utama. Selain itu, mayoritas pekerjaan yang dimiliki oleh masyarakat di desa ini adalah sebagai pengrajin sepatu/sendal yang mendapatkan pendapatkan hanya cukup untuk memenuhi keperluan sehari-hari, karena rendahnya pendidikan sehingga masyarakat tidak mampu untuk mengembangkan diri dan lingkungan desa.

2. Faktor-faktor yang mempengaruhi alokasi infak rumah tangga adalah altruisme, pendapatan serta lamanya mendapatkan pendidikan formal. Ketiga variabel tersebut memiliki pengaruh positif terhadap besarnya alokasi infak rumah tangga. Sedangkan variabel-variabel yang lainnya seperti keimanan, penghargaan, kepuasaan diri, pekerjaan, dan jumlah tanggungan tidak memiliki pengaruh nyata terdapat alokasi infak rumah tangga.

3. Perilaku pengalokasian infak pada rumah tangga di Desa Pasir Eurih, Kecamatan Tamansari, Kabupaten Bogor sudah cukup baik. Hal ini dapat dilihat dari nominal rata-rata pengalokasian infak perbulan yang dilakukan oleh masing-masing rumah tangga selain itu dapat pula dilihat dari laporan penerimaan kotak amal di desa ini. Namun donasi (zakat dan infak) belum menjadi prioritas pengeluaran yang utama di desa ini.

\section{Saran}

Berdasarkan hasil penelitian yang telah dilakukan, maka saran yang dapat diberikan berdasarkan penelitian ini adalah :

1. Masyarakat Desa Pasir Eurih diharapkan dapat menjadikan pendidikan sebagai prioritas yang utama, sehingga alokasi infak rumah tangga di desa ini dapat meningkat serta dapat pula mengembangkan desa. Apabila desa dapat lebih berkembang, pendapatan per bulan masyarakat akan meningkat serta akan meningkatkan alokasi infak masyarakat per bulannya. Selain itu perlu adanya sosialisasi dan arahan untuk membantu masyarakat dalam meningkatan keimanan sehingga nilai kereligiusan masyarakat di desa ini dapat meningkat.

2. Laporan keuangan dana infak di desa ini sebaiknya lebih akuntanble dan transparan sehingga tingkat kepercayaan masyarakat semakin tinggi dan memudahkan penelitian-penelitian selanjutnya.

3. Penelitian ini memiliki keterbatasan, yaitu : masih banyaknya variabel yang tidak dimasukkan ke dalam model. Oleh karena itu untuk penelitian selanjutnya diharapkan dapat menambahkan variabel-variabel yang mendukung misalnya seperti 
nominal jumlah tabungan rumah tangga per bulan atau nominal jumlah aset yang dimiliki.

\section{DAFTAR PUSTAKA}

Alhasanah IM. 2011. Analisis Diskriminan Faktor-Faktor yang Memengaruhi Partisipasi Berzakat Berinfak dan Pemilihan Tempat Membayar Zakat (Studi Kasus : Kabupaten Brebes) [skripsi], Bogor (ID) : Institut Pertanian Bogor.

Al-Syaikh YI. 2006. Cara Mudah Menunaikan Zakat. Bandung (ID): Salam Prima Media.

[Bappenas] Badan Perencanaan Pembangunan Nasional. 2012. Buku Panduan Evaluasi Paruh Waktu RPJMN [Internet] Tersedia dari : http://www.bappenas.go.id/files/1613/7890/3140/Buku-Evaluasi-Paruh-WaktuRPJMN_Bappenas.pdf. [Diacu 7 Juni 2014]

[BPS] Badan Pusat Statistik. [Internet]. Tersedia dari : http://www.bps.go.id// [Diacu 2 Januari 2014]

Beik IS, Tanjung H, Hakiem H, Mintarti N, dan Sutisna N. 2011. Indonesia Zakat and Development Report 2011, Jakarta (ID): Indonesia Magnificence of Zakat.

Djama MD. 2005. Menggagas Pengelolaan Zakat oleh Negara. Jakarta (ID): Nuansa Madani.

Gujarati D. dan Zain S. 1999. Ekonometrika Dasar. Jakarta (ID): Erlangga.

Hafidhuddin D. 1998. Panduan Praktis tentang Zakat, Infak Sedekah. Jakarta (ID): Gema Insani.

Hafidhuddin D. 2002. Zakat dalam Perekonomian Modern. Jakarta (ID): Gema Insani.

Hafidhuddin D dan Pramulya R. 2008. Kaya karena Berzakat. Depok (ID): Raih Asa Sukses.

Hasan MA. 2008. Zakat dan Infak Salah Satu Solusi Mengatasi Problema Sosial di Indonesia. Jakarta (ID): Kencana.

[KBBI] Kamus Besar Bahasa Indonesia. [Internet] Tersedia pada : http://kbbi.web.id/ [Diakses 5 Maret 2014].

Mas'udi MF, Djamil F, Hafidhuddin D, dan Mulia SM. 2004. Reinterpretasi Pendayagunaan ZIS menuju Efektivitas Pemanfaatan Zakat Infak Sedekah. Jakarta (ID): Piramedia.

Mukhlis A. 2011. Analisis Faktor-Faktor yang Mempengaruhi Tingkat Kepatuhan Membayar Zakat : Studi Kasus Kabupaten Bogor [skripsi]. Bogor (ID): Institut Pertanian Bogor.

Mukhlis A. dan Beik IS. 2013. Analisis Faktor-faktor yang Mempengaruhi Tingkat Kepatuhan Membayar Zakat: Studi Kasus Kabupaten Bogor. Al-Muzara'ah, 1(1).

Prihatna AA. 2005. Revitalisasi Filantropi Islam Studi Kasus Lembaga Zakat dan Wakaf di Indonesia. Jakarta (ID): The Ford Foundation.

P3EI. Ekonomi Islam. 2008. Jakarta (ID) : PT RajaGrafindo Persada.

Qadir A. 2001. Zakat dalam Dimensi Mahdhah dan Sosial. Jakarta (ID): PT Raja Grafindo.

Saesahet A. 2009. Faktor-Faktor yang Mempengaruhi Zakat Masyarakat Provinsi Pattani Thailand Selatan (Studi Kasus di daerah Prigi [skripsi]), Yogyakarta (ID): Universitas Islam Negeri Sunan Kalijaga.

Sariningrum SZ. 2011. Analisis Faktor-Faktor yang Memengaruhi Pembayaran Zakat di Kota Palembang [skripsi]. Bogor (ID): Institut Pertanian Bogor.

Sutikno, Burhan U, Khusaini M, dam Ashar K. Memaknai Perilaku Muslim dalam Bersedekah (Studi Fenomenologi Pengalaman Muzakki LAGZIS Sabilit Taqwa Bululawang), Madura (ID): Fakultas Ekonomi Universitas Trunojoyo. 
Sevilla CG, Ochave AJ, Punsalan TG, Regala BP, Uriarte GG. 1993. Pengantar Metode Penelitian. Jakarta (ID): UI-Press.

Sugiyono, 2008. Metode Penelitian Kuantitatif dan Kualitatif dan R\&D. Bandung (ID): Alfabeta.

Yogatama AR. 2009. Variabel-variabel yang Mempengaruhi Kepatuhan Menunaikan Zakat : Pendekatan Kontinjensi. [Online]. 